\title{
CXCR4 Inhibitor Q-122
}

National Cancer Institute

\section{Source}

National Cancer Institute. CXCR4 Inhibitor Q-122. NCI Thesaurus. Code C74022.

An orally bioavailable inhibitor of CXCR4 with potential antineoplastic and antiviral activities. CXCR4 inhibitor MSX-122 binds to the chemokine receptor CXCR4, preventing the binding of stromal derived factor-1 (SDF-1) to the CXCR4 receptor and receptor activation, which may result in decreased tumor cell proliferation and migration. CXCR4, a chemokine receptor belonging to the GPCR (G protein-coupled receptor) gene family, plays an important role in chemotaxis and angiogenesis and is upregulated in several tumor cell types; it is also a co-receptor for HIV entry into T cells. 